\title{
COXEN Score 33
}

National Cancer Institute

\section{Source}

National Cancer Institute. COXEN Score 33. NCI Thesaurus. Code C128230.

A score of 33 on the COXEN Sensitivity Scale. 